\title{
医師・病棟看護師が患者に 「緩和ケア」という用語を使用する時期
}

\author{
林＼cjkstart優美1,2)，小早川 誠1,2)，槙埜＼cjkstart良江 ${ }^{1,3)}$, 白川 峰子 ${ }^{1,3)}$, 重山 千恵 ${ }^{1,3)}$, \\ 山中 和子 ${ }^{4}$, 泉谷 悟4)，大下 恭子5)，中布 龍一5)，岡村 仁6)， \\ 山脇 成人 1,2$)$
}

1）広島大学病院 がん治療センター緩和ケア部門，2）広島大学大学院医歯薬保健学研究院 精神神経医科学,

3）広島大学病院 看護部，4）同 薬剂部, 5）広島大学大学院医歯薬保健学研究院 麻酔蘇生学,

6) 同 精神機能制御科学

\begin{abstract}
「緩和ケア」という用語を患者に使い難いという医療者の声を聞くことがある．用語を使うのが遅れると患者や家族 が緩和ケアを知る機会が遅れる可能性がある，われわれは「緩和ケア」という用語を用いた医療者から患者・家族への 説明について調査した. 2010 年 2 月, 広島大学病院の医師 387 名·病棟看護師 518 名に, 質問紙調査を行った. 回答率は医師 70.3\%，看護師 54.8\%で，そのうち 77.2\%の医師，56.0\%の看護師が「緩和ケア」という用語を使用 すると回答した. 過半数の医師が診断時か症状出現時にはじめて用語を使用していた. 看護師では医師が緩和ケアに ついて説明してから用語を使うとした者が約 3 割で, 臨床経験年数が少ないほどその割合は多かった. 医師は早い時 期にはじめて用語を使う者が多く，看護師は早い時期に使う者も多いが医師より先に用語を用いにくい者も少なか らずいることがわかった

Palliat Care Res 2016; 11 (3): 209-16
\end{abstract}

Key words: 緩和ケア，緩和ケアの説明，がん，コミュニケーション

\section{緒 言}

WHO は 1989 年に緩和ケアを「治癒を目指した治療が 有効でなくなった患者に対する積極的な全人的ケア」と 定義した。その後，2002 年に「生命を劦かす疾患による 問題に直面している患者とその家族に対して，疾患の 早期より行うもの」と改めている ${ }^{1)}$. 医療者に向けては, がん対策推進基本計画に基づき全国でがん医療に携わ る全ての医師を対象とする緩和ケア研修会が開催され たり，がん看護専門看護師や緩和ケア認定看護師によ る個別の教育活動が行われるなど普及啓発活動が行わ れている。しかし，一般市民に拈いても医療者において も緩和ケアに終末期医療というイメージをもつものも 少なくない2 2 7)，実臨床の場では医師から，抗がん治療 中に患者に緩和ケア外来を针めても拒否的な反応をさ

受付日 2016 年 4 月 21 日/改訂日 2016 年 7 月 12 日 / 受理日 2016 年 7 月 14 日

Corresponding Author：小早川誠

広島大学病院がん治療センター緩和ケア部門, 広島大学大学 院医歯薬保健学研究院精神神経医科学

干 734-8551 広島県広島市南区霞 1-2-3

TEL 082-257-5555 FAX 082-257-5209

E-mail: koba0515@hiroshima-u.ac.jp
れる，患者は緩和ケアを終末期医療と思っているので 「緩和ケア」を言及することに抵抗感を感じる，といっ た声を聞くことがある。英語圈でも言葉のイメージに よる使いづらさがあり，WHOの 1989 年に示された定義 は palliative care という用語, 早期から治癒可能な疾患も 含めると supportive care という用語に使い分けがなされ ていた ${ }^{3)}$ ，日本でも，緩和ケアというと患者や家族が悪 いイメージをもつため，早期からの紹介を妨げる要因 になっていることが報告されている4)。このように言葉 のもつイメージで緩和ケアの説明が遅れている可能性 が示唆されている。緩和ケアのイメージについての文 献は見つかるものの，一方で医療者がどの時期に「緩和 ケア」という用語を用いるかについての報告は，われわ れが調べた範囲ではなかった。がん患者の遺族調査で, 緩和ケアについての正確な情報が十分ではなかったと いう報告がある ${ }^{8)}$ ，緩和ケアの存在自体を知らないもの も多く2，医療者からの情報がなければ，患者や家族は 緩和ケアについて知ることもなく, 必要時に患者やそ の家族から緩和ケアを希望することもできなくなる可 能性がある。医療者が「緩和ケア」という用語を早い時 期に一度は使用していることは大切で，今後の院内広 報の方法に反映するために用語の使用状況について実 態を把握する必要があると考えた。広島大学病院に勤 
務する医師, 病棟看護師が, どのように患者・家族へ緩 和ケアについて話しているか実態を把握することを目 的に,「緩和ケア」という用語を使用する者の割合,「緩 和ケア」という用語を初めて使う時期, 緩和ケアが必要 になると思う時期について質問紙調査を行った。

\section{方 法}

広島大学病院は病床数 740 床の総合病院であり, 県の がん診療連携拠点病院に指定されている，年間の入院 患者に占めるがん患者の割合は 4 割弱で, 年間の外来が 几患者延数は約 20 万人である。緩和ケア病棟はなく， 2006 年 2 月に緩和ケアチーム診療加算のとれる緩和ケ アチームが発足し, 年間の新患は約 200 例である。緩和 ケアチームの介入に先立ち, 各診療科の主治医から, 緩 和ケアチームへ紹介することを本人，家族に伝えてい る。また, 他施設の緩和ケア病棟を勧める際の説明もほ とんどの場合主治医が行っている.

大学病院であり, 数名の医師グループとして患者を 診察している科も多く, 公式の説明に限定すると看護 師や 10 年目以下の医師では「説明自体を行わない」とす るものがほとんどになるため, 日常診療の中での説明 についての調査とした，実態調査であり，対象の全数調 査とした。本研究の対象は, 広島大学病院に扔いてがん を扱う診療科に属する医師と初期研修医全 387 名，㧍よ びがん患者の入院する病棟の看護師全518名とした，日 常診療の中での説明についての調査であり，実態調査 として初期研修医も調查対象にふくめた。しかし, 研修 医は，指導医と立場が違うために患者家族へ緩和ケア という説明をする機会が少ないことも考えられるため, 経験年数 1-2 年目の医師を除いた総計についても集計 した，本研究の実施にあたり，広島大学疫学研究倫理審 査委員会に倫理審査の申請を行い, 予備審査委員の確 認により，患者を対象としない疫学研究であり，当該委 員会の審査は要しないとされた。2010 年 2 月に各診療 科長, 各病棟看護師長に質問紙の説明, 配布と回収を依 頼した. 本研究への参加に際し謝礼は用意しなかった。 質問紙の説明文書に結果の公表を行うことを明記し, 回答した時点で結果の公表を行うことに同意したもの とした

質問紙は当時の緩和ケアチームの医師数名および看 護師数名でグループディスカッションを行い，作成し た。質問内容は以下に示す 4 項目で, 医師と看護師で若 干設問が異なる。共通のものとして(1)全員を対象に緩 和ケアについて話す時「緩和ケア」という用語を使用し て説明を行うか，(2)用語を使用する者を対象に「緩和ケ ア」という用語をはじめて使用して説明する時期, (3)用 語を使用しない者を対象にどのような言葉で緩和ケア
について説明するかの設問を設定した，医師と看護師 で異なるものとして, (4)看護師全員に, 患者にとって緩 和ケアが必要になると思う時期についての設問を設定 した，看護師からは思った時期にいいにくいと以前か ら聞くことが多かったため, 緩和ケアが必要になると 思う時期についても調査を行った。がん対策基本法で 診断時など早期からの緩和ケアや症状出現時の速やか な対応などが求められること, 当院の緩和ケアチーム 紹介時期や一般的なアドバンスケアプランニングによ る意思決定支援の推奨時期9) は症状出現時や積極的治 療困難時であること, 1989 年の WHO の定義の終末期, その他に想定される患者から聞かれた時を加えて, 時 期についての選択肢は「䛦断時」症状出現時」「積極的治 療困難時」終末期」「患者使用時」「その他」とした。看護 師への質問は先行文献にそしく，基本的には医師と同 じとし，「医師説明時」を加えた，目的が対象の全数調査 であり, 予備調査は行っていない.

主要評価項目は「緩和ケア」という用語の使用割合, 使用する場合の時期の割合, 看護師の緩和ケアが必要 になると思う時期の割合とした，本研究は実態調査で あり，探索的な検討として記述統計を主として用いた。

調查で複数回答不可にもかかわらず回答が複数あった ものや無回答のものは無効とした，各回答は医師と看 護師それぞれで解析を行った。

\section{結 果}

医師は 387 名中 272 名 $(70.3 \%)$ から回答を得た。医師 の臨床経験年数は 1-2 年 54 名 (19.9\%), 3-5 年 22 名 $(8.1 \%), 6-10$ 年 93 名 $(34.2 \%), 11$ 年以上 103 名 $(37.9 \%)$ であった，担当患者中のがん患者の割合は $0 \%$ から 100\%まで $10 \%$ 刻みで集計したところU字型に分散して いた(図 1). 臨床経験年数 1-2 年以外でのヒストグラム もほとんど変化しなかった(図 2).

また，看護師は 518 名中 284 名 $(54.8 \%)$ から回答を得 た. 看護師の臨床経験年数は 1-2 年が 81 名 $(28.5 \%)$, $3-5$ 年が 71 名 $(25.0 \%), 6-10$ 年が 60 名 $(21.1 \%), 11$ 年 以上が 72 名 $(25.4 \%)$ であった。

\section{1. 医師の結果}

（1）「緩和ケア」という用語を使用して説明を行うか 全体では「緩和ケア」という用語を使用して説明する

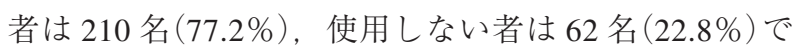
あった(表 1)。臨床経験年数別では,「緩和ケア」という 用語を使用する割合はそれぞれ 1-2 年 $59.3 \% ， 3-5$ 年 $86.4 \%, 6-10$ 年 $81.7 \%, 11$ 年以上 $80.6 \%$ であり(表 1), 1-2 年では「緩和ケア」という用語を使用する割合がや や低かった。経験年数 1-2 年以外では, 用語を使用して 説明する者は 178 名 $(81.7 \%)$, 使用しない者は 40 名 


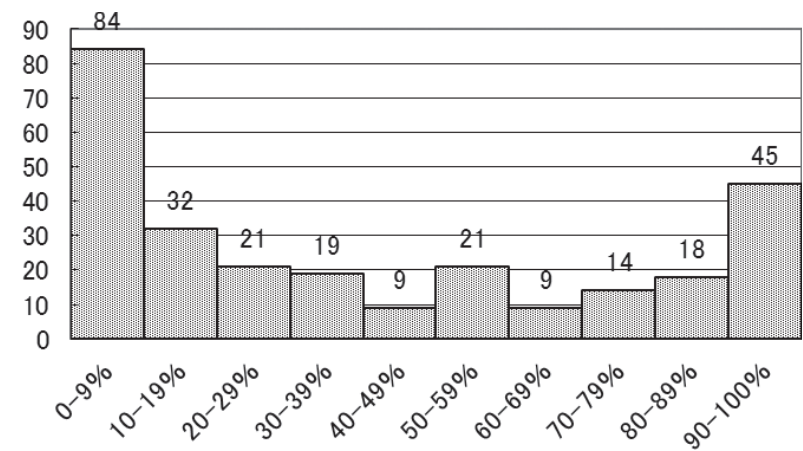

図 1 医師の担当患者中のがん患者の割合

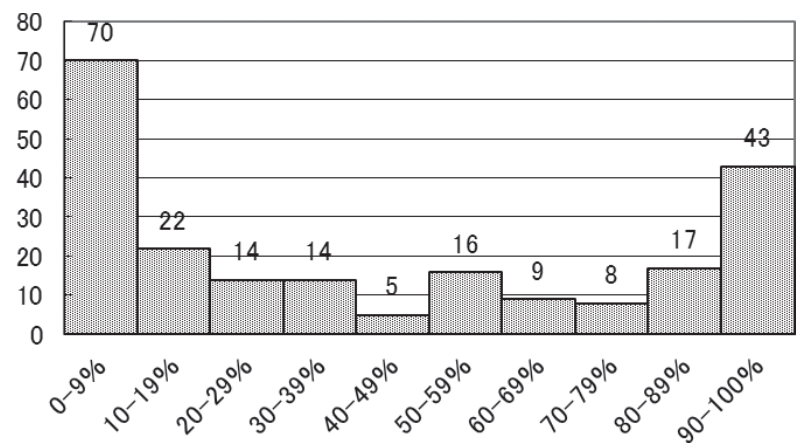

図 2 医師の担当患者中のがん患者の割合 一臨床経験年数 1-2 年以外一

表 1 医師と看護師の臨床経験年数と「緩和ケア」という用語の使用状況, 用語を使用する時期, 看護師の緩和ケアが必要になると考える時期

\begin{tabular}{|c|c|c|c|c|c|c|c|c|c|c|c|}
\hline & \multicolumn{6}{|c|}{$\begin{array}{c}\text { 医師 } \\
\text { 経験年数 }\end{array}$} & \multicolumn{5}{|c|}{$\begin{array}{c}\text { 看護師 } \\
\text { 経験年数 }\end{array}$} \\
\hline & $\begin{array}{l}\text { 総 } \\
(\%)\end{array}$ & $\begin{array}{c}1-2 \text { 年 } \\
\text { 以外(\%) }\end{array}$ & $\begin{array}{c}1-2 \text { 年 } \\
(\%)\end{array}$ & $\begin{array}{c}3-5 \text { 年 } \\
(\%)\end{array}$ & $\begin{array}{c}6-10 \text { 年 } \\
(\%)\end{array}$ & $\begin{array}{l}11 \text { 年 } \\
\text { 以上 } \%)\end{array}$ & $\begin{array}{l}\text { 総 } \\
(\%)\end{array}$ & $\begin{array}{c}1-2 \text { 年 } \\
(\%)\end{array}$ & $\begin{array}{c}3-5 \text { 年 } \\
(\%)\end{array}$ & $\begin{array}{c}6-10 \text { 年 } \\
(\%)\end{array}$ & $\begin{array}{l}11 \text { 年 } \\
\text { 以上 } \%)\end{array}$ \\
\hline \multicolumn{12}{|l|}{ 用語の使用 } \\
\hline あり & $\begin{array}{c}210 \\
(77.2)\end{array}$ & $\begin{array}{c}178 \\
(81.7)\end{array}$ & $\begin{array}{r}32 \\
(59.3)\end{array}$ & $\begin{array}{c}19 \\
(86.4)\end{array}$ & $\begin{array}{r}76 \\
(81.7)\end{array}$ & $\begin{array}{c}83 \\
(80.6)\end{array}$ & $\begin{array}{c}159 \\
(56.0)\end{array}$ & $\begin{array}{c}39 \\
(48.1)\end{array}$ & $\begin{array}{c}39 \\
(54.9)\end{array}$ & $\begin{array}{c}32 \\
(53.3)\end{array}$ & $\begin{array}{c}49 \\
(68.1)\end{array}$ \\
\hline なし & $\begin{array}{c}62 \\
(22.8)\end{array}$ & $\begin{array}{c}40 \\
(18.3)\end{array}$ & $\begin{array}{c}22 \\
(40.7)\end{array}$ & $\begin{array}{c}3 \\
(13.6)\end{array}$ & $\begin{array}{c}17 \\
(18.3)\end{array}$ & $\begin{array}{c}20 \\
(19.4)\end{array}$ & $\begin{array}{c}125 \\
(44.0)\end{array}$ & $\begin{array}{c}42 \\
(51.9)\end{array}$ & $\begin{array}{c}32 \\
(45.1)\end{array}$ & $\begin{array}{c}28 \\
(46.7)\end{array}$ & $\begin{array}{c}23 \\
(31.9)\end{array}$ \\
\hline \multicolumn{12}{|l|}{$\begin{array}{l}\text { 用語を使用した } \\
\text { 説明時期 }\end{array}$} \\
\hline 診断時 & $\begin{array}{c}19 \\
(10.8)\end{array}$ & $\begin{array}{c}18 \\
(12.5)\end{array}$ & $\begin{array}{c}1 \\
(3.1)\end{array}$ & $\begin{array}{c}4 \\
(26.7)\end{array}$ & $\begin{array}{c}6 \\
(10.0)\end{array}$ & $\begin{array}{c}8 \\
(11.6)\end{array}$ & $\begin{array}{c}5 \\
(4.2)\end{array}$ & $\begin{array}{c}0 \\
(0.0)\end{array}$ & $\begin{array}{c}0 \\
(0.0)\end{array}$ & $\begin{array}{c}0 \\
(0.0)\end{array}$ & $\begin{array}{c}5 \\
(13.9)\end{array}$ \\
\hline 症状出現時 & $\begin{array}{c}100 \\
(56.8)\end{array}$ & $\begin{array}{c}82 \\
(56.9)\end{array}$ & $\begin{array}{c}18 \\
(56.3)\end{array}$ & $\begin{array}{c}7 \\
(46.7)\end{array}$ & $\begin{array}{c}34 \\
(56.7)\end{array}$ & $\begin{array}{c}41 \\
(59.4)\end{array}$ & $\begin{array}{c}52 \\
(44.1)\end{array}$ & $\begin{array}{c}5 \\
(16.1)\end{array}$ & $\begin{array}{c}15 \\
(50.0)\end{array}$ & $\begin{array}{c}10 \\
(47.6)\end{array}$ & $\begin{array}{c}22 \\
(61.1)\end{array}$ \\
\hline 治療困難時 & $\begin{array}{c}27 \\
(15.3)\end{array}$ & $\begin{array}{c}24 \\
(16.7)\end{array}$ & $\begin{array}{c}3 \\
(9.4)\end{array}$ & $\begin{array}{c}1 \\
(6.7)\end{array}$ & $\begin{array}{c}11 \\
(18.3)\end{array}$ & $\begin{array}{c}12 \\
(17.4)\end{array}$ & $\begin{array}{c}3 \\
(2.5)\end{array}$ & $\begin{array}{c}1 \\
(3.2)\end{array}$ & $\begin{array}{c}0 \\
(0.0)\end{array}$ & $\begin{array}{c}0 \\
(0.0)\end{array}$ & $\begin{array}{c}2 \\
(5.6)\end{array}$ \\
\hline 終末期 & $\begin{array}{c}25 \\
(14.2)\end{array}$ & $\begin{array}{c}17 \\
(11.8)\end{array}$ & $\begin{array}{c}8 \\
(25.0)\end{array}$ & $\begin{array}{c}3 \\
(20.0)\end{array}$ & $\begin{array}{c}7 \\
(11.7)\end{array}$ & $\begin{array}{c}7 \\
(10.1)\end{array}$ & $\begin{array}{c}10 \\
(8.5)\end{array}$ & $\begin{array}{c}4 \\
(12.9)\end{array}$ & $\begin{array}{c}4 \\
(13.3)\end{array}$ & $\begin{array}{c}1 \\
(4.8)\end{array}$ & $\begin{array}{c}1 \\
(2.8)\end{array}$ \\
\hline 患者使用時 & $\begin{array}{c}2 \\
(1.1)\end{array}$ & $\begin{array}{c}1 \\
(0.7)\end{array}$ & $\begin{array}{c}1 \\
(3.1)\end{array}$ & $\begin{array}{c}0 \\
(0.0)\end{array}$ & $\begin{array}{c}1 \\
(1.7)\end{array}$ & $\begin{array}{c}0 \\
(0.0)\end{array}$ & $\begin{array}{c}11 \\
(9.3)\end{array}$ & $\begin{array}{c}5 \\
(16.1)\end{array}$ & $\begin{array}{c}3 \\
(10.0)\end{array}$ & $\begin{array}{c}2 \\
(9.5)\end{array}$ & $\begin{array}{c}1 \\
(2.8)\end{array}$ \\
\hline 医師説明後 & & & & & & & $\begin{array}{c}37 \\
(31.4)\end{array}$ & $\begin{array}{c}16 \\
(51.6)\end{array}$ & $\begin{array}{c}8 \\
(26.7)\end{array}$ & $\begin{array}{c}8 \\
(38.1)\end{array}$ & $\begin{array}{c}5 \\
(13.9)\end{array}$ \\
\hline その他 & $\begin{array}{c}3 \\
(1.7)\end{array}$ & $\begin{array}{c}2 \\
(1.4)\end{array}$ & $\begin{array}{c}1 \\
(3.1)\end{array}$ & $\begin{array}{c}0 \\
(0.0)\end{array}$ & $\begin{array}{c}1 \\
(1.7)\end{array}$ & $\begin{array}{c}1 \\
(1.4)\end{array}$ & $\begin{array}{c}0 \\
(0.0)\end{array}$ & $\begin{array}{c}0 \\
(0.0)\end{array}$ & $\begin{array}{c}0 \\
(0.0)\end{array}$ & $\begin{array}{c}0 \\
(0.0)\end{array}$ & $\begin{array}{c}0 \\
(0.0)\end{array}$ \\
\hline $\begin{array}{l}\text { 緩和ケアが必要に } \\
\text { なる思う時期 }\end{array}$ & & & & & & & & & & & \\
\hline 診断時 & & & & & & & $\begin{array}{c}116 \\
(43.6)\end{array}$ & $\begin{array}{c}23 \\
(30.7)\end{array}$ & $\begin{array}{c}31 \\
(45.6)\end{array}$ & $\begin{array}{c}22 \\
(39.3)\end{array}$ & $\begin{array}{c}40 \\
(59.7)\end{array}$ \\
\hline 症状出現時 & & & & & & & $\begin{array}{c}120 \\
(45.1)\end{array}$ & $\begin{array}{c}43 \\
(57.3)\end{array}$ & $\begin{array}{c}30 \\
(44.1)\end{array}$ & $\begin{array}{c}23 \\
(41.1)\end{array}$ & $\begin{array}{c}24 \\
(35.8)\end{array}$ \\
\hline 治療困難時 & & & & & & & $\begin{array}{c}18 \\
(6.8)\end{array}$ & $\begin{array}{c}6 \\
(8.0)\end{array}$ & $\begin{array}{c}3 \\
(4.4)\end{array}$ & $\begin{array}{c}6 \\
(10.7)\end{array}$ & $\begin{array}{c}3 \\
(4.5)\end{array}$ \\
\hline 終末期 & & & & & & & $\begin{array}{c}5 \\
(1.9)\end{array}$ & $\begin{array}{c}1 \\
(1.3)\end{array}$ & $\begin{array}{c}1 \\
(1.5)\end{array}$ & $\begin{array}{c}3 \\
(5.4)\end{array}$ & $\begin{array}{c}0 \\
(0.0)\end{array}$ \\
\hline その他 & & & & & & & $\begin{array}{c}7 \\
(2.6)\end{array}$ & $\begin{array}{c}2 \\
(2.7)\end{array}$ & $\begin{array}{c}3 \\
(4.4)\end{array}$ & $\begin{array}{c}2 \\
(3.6)\end{array}$ & $\begin{array}{c}0 \\
(0.0)\end{array}$ \\
\hline
\end{tabular}




\begin{tabular}{|c|c|c|c|c|c|c|c|c|c|c|}
\hline & \multicolumn{10}{|c|}{ 医師の担当患者中のがん患者の割合 } \\
\hline & $\begin{array}{l}0-9 \\
(\%)\end{array}$ & $\begin{array}{c}10-19 \\
(\%)\end{array}$ & $\begin{array}{c}20-29 \\
(\%)\end{array}$ & $\begin{array}{c}30-39 \\
(\%)\end{array}$ & $\begin{array}{c}40-49 \\
(\%)\end{array}$ & $\begin{array}{c}50-59 \\
(\%)\end{array}$ & $\begin{array}{c}60-69 \\
(\%)\end{array}$ & $\begin{array}{c}70-79 \\
(\%)\end{array}$ & $\begin{array}{c}80-89 \\
(\%)\end{array}$ & $\begin{array}{c}90-100 \\
(\%)\end{array}$ \\
\hline \multicolumn{11}{|l|}{ 用語の使用 } \\
\hline あり & $\begin{array}{c}60 \\
(71.4)\end{array}$ & $\begin{array}{c}23 \\
(71.9)\end{array}$ & $\begin{array}{c}15 \\
(71.4)\end{array}$ & $\begin{array}{c}14 \\
(73.7)\end{array}$ & $\begin{array}{c}5 \\
(55.6)\end{array}$ & $\begin{array}{c}18 \\
(85.7)\end{array}$ & $\begin{array}{c}9 \\
(100)\end{array}$ & $\begin{array}{c}12 \\
(85.7)\end{array}$ & $\begin{array}{c}15 \\
(83.3)\end{array}$ & $\begin{array}{c}39 \\
(86.7)\end{array}$ \\
\hline なし & $\begin{array}{c}24 \\
(28.6)\end{array}$ & $\begin{array}{c}9 \\
(28.1)\end{array}$ & $\begin{array}{c}6 \\
(28.6)\end{array}$ & $\begin{array}{c}5 \\
(26.3)\end{array}$ & $\begin{array}{r}4 \\
(44.4)\end{array}$ & $\begin{array}{c}3 \\
(14.3)\end{array}$ & $\begin{array}{c}0 \\
(0.0)\end{array}$ & $\begin{array}{c}2 \\
(14.3)\end{array}$ & $\begin{array}{c}3 \\
(16.7)\end{array}$ & $\begin{array}{c}6 \\
(13.3)\end{array}$ \\
\hline \multicolumn{11}{|c|}{$\begin{array}{l}\text { 用語を使用した } \\
\text { 説明時期 }\end{array}$} \\
\hline 診断時 & 7 & 4 & 0 & 2 & 0 & 1 & 0 & 0 & 1 & 4 \\
\hline & $(13.7)$ & $(20.0)$ & $(0.0)$ & $(16.7)$ & $(0.0)$ & $(6.3)$ & $(0.0)$ & $(0.0)$ & $(8.3)$ & $(12.1)$ \\
\hline 症状出現時 & $\begin{array}{c}23 \\
(45.1)\end{array}$ & $\begin{array}{c}10 \\
(50.0)\end{array}$ & $\begin{array}{c}9 \\
(69.2)\end{array}$ & $\begin{array}{c}10 \\
(83.3)\end{array}$ & $\begin{array}{c}2 \\
(50.0)\end{array}$ & $\begin{array}{c}7 \\
(43.8)\end{array}$ & $\begin{array}{c}4 \\
(80.0)\end{array}$ & $\begin{array}{c}5 \\
(50.0)\end{array}$ & $\begin{array}{c}8 \\
(66.7)\end{array}$ & $\begin{array}{c}22 \\
(66.7)\end{array}$ \\
\hline 治療困難時 & $\begin{array}{c}7 \\
(13.7)\end{array}$ & $\begin{array}{c}1 \\
(5.0)\end{array}$ & $\begin{array}{r}2 \\
(15.4)\end{array}$ & $\begin{array}{c}0 \\
(0.0)\end{array}$ & $\begin{array}{c}1 \\
(25.0)\end{array}$ & $\begin{array}{c}4 \\
(25.0)\end{array}$ & $\begin{array}{c}1 \\
(20.0)\end{array}$ & $\begin{array}{c}3 \\
(30.0)\end{array}$ & $\begin{array}{r}2 \\
(16.7)\end{array}$ & $\begin{array}{c}6 \\
(18.2)\end{array}$ \\
\hline 終末期 & $\begin{array}{c}13 \\
(25.5)\end{array}$ & $\begin{array}{c}4 \\
(20.0)\end{array}$ & $\begin{array}{c}1 \\
(7.7)\end{array}$ & $\begin{array}{c}0 \\
(0.0)\end{array}$ & $\begin{array}{c}1 \\
(25.0)\end{array}$ & $\begin{array}{c}3 \\
(18.8)\end{array}$ & $\begin{array}{c}0 \\
(0.0)\end{array}$ & $\begin{array}{c}2 \\
(20.0)\end{array}$ & $\begin{array}{c}1 \\
(8.3)\end{array}$ & $\begin{array}{c}0 \\
(0.0)\end{array}$ \\
\hline 患者使用時 & $\begin{array}{c}1 \\
(2.0)\end{array}$ & $\begin{array}{c}0 \\
(0.0)\end{array}$ & $\begin{array}{c}0 \\
(0.0)\end{array}$ & $\begin{array}{c}0 \\
(0.0)\end{array}$ & $\begin{array}{c}0 \\
(0.0)\end{array}$ & $\begin{array}{c}1 \\
(6.3)\end{array}$ & $\begin{array}{c}0 \\
(0.0)\end{array}$ & $\begin{array}{c}0 \\
(0.0)\end{array}$ & $\begin{array}{c}0 \\
(0.0)\end{array}$ & $\begin{array}{c}0 \\
(0.0)\end{array}$ \\
\hline その他 & $\begin{array}{c}0 \\
(0.0)\end{array}$ & $\begin{array}{c}1 \\
(5.0)\end{array}$ & $\begin{array}{c}1 \\
(7.7)\end{array}$ & $\begin{array}{c}0 \\
(0.0)\end{array}$ & $\begin{array}{c}0 \\
(0.0)\end{array}$ & $\begin{array}{c}0 \\
(0.0)\end{array}$ & $\begin{array}{c}0 \\
(0.0)\end{array}$ & $\begin{array}{c}0 \\
(0.0)\end{array}$ & $\begin{array}{c}0 \\
(0.0)\end{array}$ & $\begin{array}{c}1 \\
(3.0)\end{array}$ \\
\hline
\end{tabular}

(18.3\%)であった(表 1)．また，担当患者中のがん患者 の割合別でも各群 60-85\%で特徵はなかった(表 2).

(2)「緩和ケア」という用語をはじめて使用する場合の 説明時期

「緩和ケア」という用語を使用して説明すると回答し た医師 210 名のうち, どの時期にはじめて緩和ケアの説 明を行うかという設問に対して 176 名の有効回答を得 た。“症状出現時”が 100 名 $(56.8 \%)$ ともっとも多く, “積 極的治療困難時”27名 (15.3\%), “終末期” 25 名 (14.2\%), “診断時” 19 名 (10.8\%), “患者使用時” 2 名 $(1.1 \%)$, “它 の他”3 名 (1.7\%) と続いた(表 1)。その他では, “治療中 のがんだけでなく基礎疾患に伴う痛みが出始めたと き”，“場合により変わる”という回答がみられた。経験 年数別, がん患者割合別でもほぼ同じ順で特徴はな かった(表 1, 表 2)。経験年数 1-2 年以外では, “症状出 現時”82名 (56.9\%), “積極的治療困難時”24名 (16.7\%), “診断時” 18 名 (12.5\%), “終末期” 17 名 (11.8\%), “その 他”2 名 $(1.4 \%)$, “患者使用時” 1 名 $(0.7 \%)$ の順であった (表 1).

（3）「緩和ケア」という用語を使用しない場合に，どの ような言葉で説明するか

“疼痛コントロール”, “精神科”, “精神的サポート”, “心身の苦痛をとる治療”といった, 痛みや苦痛, 不安な どの症状を和らげる医療という内容の説明が 32 名で最 も多かった. 複数のいい方を症状ごとに使い分けると した回答も多かった。他に, 療養生活の質を上げるため のサポートという内容の説明が2名みられた。一方で, 説明せず導入するものが 2 名, “終末期ケア”というもの
も1名もみられた，説明する機会がないと回答したもの が 2 名あった. 23 名は無回答であった.

\section{2. 看護師の結果}

（1）「緩和ケア」という用語を使用して説明を行うか

日常業務の中で緩和ケア」という用語を使用する者 は 159 名 $(56.0 \%)$, 使用しない者は 125 名 (44.0\%)で あった(表 1)。臨床経験年数別では,「緩和ケア」という 用語を使用する割合はそれぞれ 1-2 年 48.1\%，3-5 年 $54.9 \%, 6-10$ 年 $53.3 \%, 11$ 年以上 $68.1 \%$ であり (表 1), 臨床経験年数が多いほど使用するものの割合が高く なった。

（2）「緩和ケア」という用語をはじめて使用する場合の 説明時期

「緩和ケア」という用語を使用する 159 名に対して 行った，「緩和ケア」という用語を初めて使用する時期 についての設問に対して 118 名の有効回答が得られた. “症状出現時”が 52 名 $(44.1 \%)$ と最も多く, 次いで“医師 説明時”が 37 名 (31.4\%), “患者使用時” 11 名 (9.3\%), “終末期” 10 名 (8.5\%), “診断時” 5 名 (4.2\%), “積極的治 療困難時” 3 名 (2.5\%) と続いた(表 1). 臨床経験年数が 少ない群ほど“医師説明時”や“患者使用時”, “終末期” に説明するとした割合が高く, 臨床経験年数が多い群 ほど“症状出現時”の割合が高い傾向にあった。また， “診断時”は臨床経験年数 11 年以上の群のみで認めら れた。

（3）「緩和ケア」という用語を使用しない場合に，どの ような言葉で説明するか

“疼痛コントロール”, “苦痛をとる”, “精神的ケア”, 
“全面的ケア”といった, 痛みや苦痛, 不安などの症状を 和らげる医療やケアという内容の説明が 57 名で最も多 かった。他に，“体力をつけるために少し休む”，“話を 聴いてくれるスタッフ”, “終末期をその人らしく過ご すためのもの”というものが 1 名ずつみられた。説明す ることがないと回答したものが 32 名, 33 名は無回答で あった。

（4）緩和ケアが必要になると思う時期

回答した全看護師 284 名に対して行った, 緩和ケアが 必要になると思う時期についての設問に対して266名 の有効回答が得られた。“症状出現時”が 120 名 (45.1\%), 次いで“診断時” 116 名 (43.6\%), “積極的治療 困難時” 18 名 $(6.8 \%)$, “終末期” 5 名 (1.9\%), “その他” 7 名 $(2.6 \%)$ であった(表 1). その他の内容については, “症状が出る直前くらいから”, “社会的なものも含めて 症状や問題が生じた時”, “がん自体の治療以外でも苦 痛を伴う治療時”, “治療開始時”, “症状コントロールが 不良になった時”，“患者・家族が必要としたとき”など であった．臨床経験年数別でみても，回答の多い順序は 変わらなかった。

\section{考 察}

実態調査であり，結果は仮説を検討したものではな い. 経験年数の分布は, 都市部の大学病院として標準的 かどうか, 全国平均がないため比較ができない. 病院の 構成は各病院ごと, 地域ごとでも異なるため, 結果は他 院とは単純に比較はできない.

本研究の対象にはがん患者と関わらない者が含まれ ているが, それでも「緩和ケア」という言葉を使用する ものは医師の 8 割弱, 看護師の 6 割弱であった. 他に比 べることのできる研究がないため, 多寡を論じること ができないが, 緩和ケアを必要とする患者に情報が伝 わるという点ではこの割合は高い方が望ましい.「緩和 ケア」という用語を使用しないとした医師もいたが, 説 明する機会がないわけではなく，緩和ケアについて何 かしらの説明をしていた。基本的緩和ケアの知識は全 ての医師が持てるようにという潮流を後押しするもの と考えられる。

「緩和ケア」という用語を使わない場合に，医師，看護 師とも身体的・精神的な症状のコントロールとして説 明することが最も多かった。苦痛を減らすという点で 意罒が十分伝われば問題はないと考える。しかし少数 ではあるが，終末ケアや終末期のケアとして説明した ものもあった．状況によっては終末期という用語を使 うことで患者の病状理解がすすむ場合もあるが, 終末 期以前の必要な時期に症状緩和を行えないこともおこ りうる。詳細を確認するには, 別の研究が必要である.
「緩和ケア」という用語を使用して説明する時期につ いて, 医師の回答は“診断時”と“症状出現時”が 6 割強, “積極的治療困難時”と“終末期”が 3 割であった。「緩和 ケア」という用語を用いて説明する時期は, 必ずしも専 門的緩和ケアを紹介する時期とはならない. 時期が早 すぎると説明した内容を患者やその家族が忘れてしま うこともあり得るが, 情報がないと選択はできないた め, 患者が困った時に緩和ケアの相談ができるよう, 早 い段階で一度は「緩和ケア」という用語を用いた説明を することが勧められる。 ホスピスについて医師が話題 にすることは遅くなりがちであり ${ }^{6,10,11)}$ ，ホスピスだけ でなく「緩和ケア」という用語を使う時期についても同 様のことが予測されたが, 本研究の医師の回答では,

「緩和ケア」という用語を使用するとした医師のうち過 半数が “診断時”か “症状出現時”に「緩和ケア」という言 葉を使用して説明を行うとしており，おおむね早めに 説明がされていると考えられた。緩和ケアについて患 者やその家族が本やインターネットなどで主体的に調 べるようになってきたとはいえ，医師や看護師から説 明してくれるものだと思っていたという患者もおり， 医療者側からの早めの情報発信は重要である。治療も ホスピスも時期や勧め方は医師個人の好みが反映され やすい ${ }^{12 \sim 14)}$. 用語を用いるのが遅くなる約 30\%につい ては, 医師の好みを変革するものとして, 患者に早めに 情報が入ることがよいことと医師が実感することが可 能性のあるものと考えられる。医療者からいわれるよ り前に，患者が緩和ケアについての情報を得やすいよ う，患者向けの病院内の掲示や案内の工夫する必要が ある。

病棟看護師の回答は, “緩和ケアが必要になると思う 時期”は“診断時”と“症状出現時”を併せて約 9 割であ り，回答した看護師にもWHO の 2002 年の定義は認識 されてきていることが示唆された。今回のわれわれの 調査では臨床経験年数でほとんど差はなかった。日本 の看護師を対象としたがん性疼痛の学習の時期につい ての調査では，学生時代に授業で習ったとしたものが 全体では最も多かったが, 就職後の学習の中では院内, 院外の勉強会によるものが最も多く, 次いで先輩から 習ったものだったという報告がある ${ }^{15)}$. 2002 年に定義 が変わっており, 経験年数が 8 年より多いものは卒後教 育によって知識を得ている。卒前教育については病院 から情報発信は難しい。“治療困難時”と“終末期”とい う回答も臨床経験年数にかかわらずまだみられており， 看護師向け院内勉強会でのさらなる啓発活動を続けて いく必要がある。

早期から患者に緩和ケアが必要になると考えている 一方で，実際に病棟看護師が「緩和ケア」という用語を 使用して説明する時期は，医師が説明した時と回答し 
たものが約 3 割と多く，医師の説明より先に「緩和ケア」 という用語を使用しにくい看護師がいることが示唆さ れた。経験年数が少ないほど医師の説明の前に「緩和ケ ア」という用語を使用しにくく, 経験年数が多いほど症 状出現時や診断時などに医師の説明にかかわらず「緩和 ケア」という用語を使用する傾向がみられた，経験年数 により変化することから, 臨床経験の積み重ねにより,

患者と接していて必要と気付いた時に自分で緩和ケア についての説明ができるようになる可能性が考えられ る. 専門看護師の活動により, スタッフの意識変化が揖 こるという報告もある ${ }^{16)}$ が，勉強会後の知識を確認し た報告はあるが，実際の行動が変化したという研究は なく, 結論を得るには別の研究が必要である。また，患 者の症状は医師よりも看護師の方が正確に把握してい たという報告がある ${ }^{17)}$ 。もし早めに医師から緩和ケア についての説明がされていなかった場合，必要時に患 者と看護師が緩和ケアについて話題にできないままと なり，患者の不利益につながる可能性も考えられる。そ の上, 緩和ケアの方針について医師-看護師間の意思疎 通がスムーズでないと看護師にとって大きなストレス になることがある ${ }^{18)}$ ，患者の症状や問題点を医療者間 で把握し，患者個人の状況にあわせた説明方法や説明 者を考え，適切な話し合いが行えるよう，日ごろからよ いコミュニケーションをはかれる環境が大切である.

本研究では結果を解釈するにあたりいくつかの限界 がある。(1)調查施設は大学病院という高度ながん診療 と教育活動を重点的に担う施設であり, より一般的な 病院の医師, 看護師での調查は行っていないため, 一般 化するには十分ではない. (2)緩和ケアに対して興味の 少ない医師，看護師ほど回答を行わなかった可能性が ある. (3)看護師は病棟勤務の看護師のみを刘象として おり，がん診療に携わる外来看護師は今回の調查対象 に含まれていない. (4)予備調査を行っていないため, 信 頼性は確保されて抢らず, 表面的妥当性, 内容的妥当性 が検証されていない，(5)性別，診療科，年間の担当がん 患者数や看取り患者数, 緩和ケアチームへのコンサル 卜数, 緩和ケアの研修歴など, 背景の情報収集にそし く, 結果の詳細な解析や外的妥当性の検討が難しい. し たがって, 明確な結論を得るにはこれらの限界を考慮 した上で, 質問紙の改良, 対象者の拡大または限定, 単 施設だけでなく多施設調査など，方法を修正したさら なる検討が必要である.

\section{結 論}

患者や家族にとって適切な時期に緩和ケアの介入が 行えるよう, 緩和ケアについての初回の説明は早く行 われることが望まれる。 今回の結果からは, 多くの医師
が「緩和ケア」という用語を用いた説明を比較的早期に 行っていることが示唆された. 多くの看護師も「緩和ケ ア」という用語を使用して患者と話ができているが, 看 護師は医師が説明するより先に「緩和ケア」という用語 を使いにくいにくい傾向がみられた，緩和ケアの教育， 普及活動とともに，医療者間のよいコミュニケーショ ンをはかれる環境が大切である。

謝辞 本研究の施行にあたり, 貴重な時間を割いてアンケート にご協力いただいた広島大学病院の医師, 看護師の皆様に感謝 の意を表します。

著者の申告すべき利益相反なし

\section{文 献}

1) Sepulveda C, Marlin A, Yoshida T, et al. Palliative care: the World Health Organization's global perspective. J Pain Symptom Manage 2002; 24: 91-6.

2）江口研二, 秋山美紀, 秋月伸哉, 他.「緩和ケア普及の ための地域プロジェクト」対象地域に対する予備調査. 厚生労働科学研究費補助金第 3 次対がん総合戦略研 究事業 緩和ケアプログラムによる地域介入研究 平成 19 年度総括研究報告書, 2008 .

3) Fadul N, Elsayem A, Palmer JL, et al. Supportive versus palliative care: what's in a name? Cancer 2009; 115: 2013-21.

4) Miyashita M, Hirai K, Morita T, et al. Barriers to referral to impatient palliative care units in Japan: a qualitative survey with content analysis. Support Care Cancer 2008; 16: 21722.

5) Miyashita M, Sanjo M, Morita T, et al. Barriers to providing palliative care and priorities for future action to advance palliative care in Japan: a nationwide expert opinion survey. J Palliat Med 2007; 10: 390-9.

6) Morita $T$, Akechi $T$, Ikenaga $M$, et al. Late referrals to specialized palliative care service in Japan. J Clin Oncol 2005; 23: 2637-44.

7) Sanjo M, Miyashita M, Morita T, et al. Perceptions of specialized inpatient palliative care: a population-based survey in Japan. J Pain Symptom Manage 2008; 35: 275-82.

8) Shiozaki M, Morita T, Hirai K, et al. Why are bereaved family members dissatisfied with specialized inpatient palliative care service? A nationwide qualitative study. Palliat Med 2005; 19: 319-27.

9) Saaraiya B, Bodnar-Deren S, Leventhal E, et al. End of life planning and its relevance for patients and oncologists' decisions in choosing cancer therapy. Cancer 2008; 113: 3540-7.

10) Keating NL, Landrum MB, Rogers SO, et al. Physician factors associated with discussions about end-of-life care. Cancer 2010; 116: 998-1006.

11) Morita $T$, Miyashita $M$, Tuneto $S$, et al. Late referrals to palliative care units in Japan: nationwide follow-up survey and effect of palliative care team involvement after the cacner control act. J Pain Symptom Manage 2009; 38: 191-6.

12) Chinn GM, Liu P-H, Klabunde CN, et al. Physicians' preferences for hospice if they were terminally ill and the timing of 
hospice discussions with their patients. JAMA 2014; 174: 466-8.

13) Gramelspacher GP, Zhou X-H, Hanna MP, et al. Preferences of physicians and their patients for end-of-life care. J Gen Intern Med 1997; 12: 346-51.

14) Ubel PA, Angott AM, Zikmund-Fisher BJ. Physicians recommend different treatments for patients than they would choose for themselves. Arch Intern Med 2011; 171: 630-4.

15）平野茂樹，宇都宮純平，出口裕子，他．がん疼痛管理に 関する看護師への教育支援を目的とした実態調査。日 病薬師会誌 2009; 45: 1365-9.
16）大田有美, 高橋奈美, 田中結美. 赤十字病院に所属する 専門看護師の活動の現状分析 2. 日赤医学 2010; 62: 241.

17) Cirillo M, Venturini M, Ciccarelli L, et al. Clinician versus nurse symptom reporting using the National Cancer InstituteCommon Terminology Criteria for Adverse Events during chemotherapy: results of a comparison based on patient's self-reported questionnaire. Annals of Oncology 2009; 20: 1929-35.

18）松本俊子。一般病棟での緩和ケア (3) 一般病棟のメ リットとデメリット． Nursing Today 2005; 20: 18-20. 


\title{
Original Research
}

\section{Timing of Use of the Term "Palliative Care" for Cancer Patients by Physicians and Nurses in Japan}

\author{
Yumi Hayashi, ${ }^{1,2)}$ Makoto Kobayakawa, ${ }^{1,2)}$ Yoshie Makino, ${ }^{1,3)}$ Mineko Shirakawa,,3) \\ Chie Shigeyama, ${ }^{1,3)}$ Kazuko Yamanaka, ${ }^{4)}$ Satoru Izumitani, ${ }^{4}{ }^{4}$ Kyouko Oshita, ${ }^{5)}$ \\ Ryuichi Nakanuno, ${ }^{5)}$ Hitoshi Okamura, ${ }^{6)}$ and Shigeto Yamawaki ${ }^{1,2)}$ \\ 1) Department of Palliative Care, Cancer Treatment Center, Hiroshima University Hospital, \\ 2) Department of Psychiatry and Neurosciences, Institute of Biomedical and Health Sciences, Hiroshima University, \\ 3) Department of Nurse, Hiroshima University Hospital, \\ 4) Department of Pharmaceutical Services, ditto, \\ 5) Department of Anesthesiology and Critical Care, Institute of Biomedical and Health Sciences, Hiroshima University, \\ 6) Department of Psychosocial Rehabilitation, ditto
}

Palliative care is sometimes difficult for medical staff to say to patients with cancer and their families. The late of using the term "palliative care" decrease the opportunity to know about palliative care for the patients and their families. The primary aims of this study were to reveal physicians' and nurses' usage of the term "palliative care", time to use the term for the first time, and a synonym. We conducted a questionnaire survey to 387 physicians and 518 floor nurses at Hiroshima University Hospital in February, 2010. We analyzed the results of physicians and nurses separately. Two hundred and seventy-two physicians (response rate 70.3\%) and 284 nurses (54.8\%) answered the questionnaire. Many physicians (77.2\%) and the majority of nurses (56.0\%) explain with the term "palliative care". the majority of physicians use the term when cancer cause any symptoms and at early stage. Some nurses $(31.4 \%)$ couldn't use the term "palliative care" before physicians explained the term. Nurses having longer experience tend to use the term regardless of physicians' use. Many physicians use the term "palliative care" at early stage of cancer. Many nurses also use the term at early stage of cancer, but some nurses couldn't use before physicians' use.

Palliat Care Res 2016; $11(3):$ 209-16

Key words: palliative care, explanation of palliative care, cancer, communication 